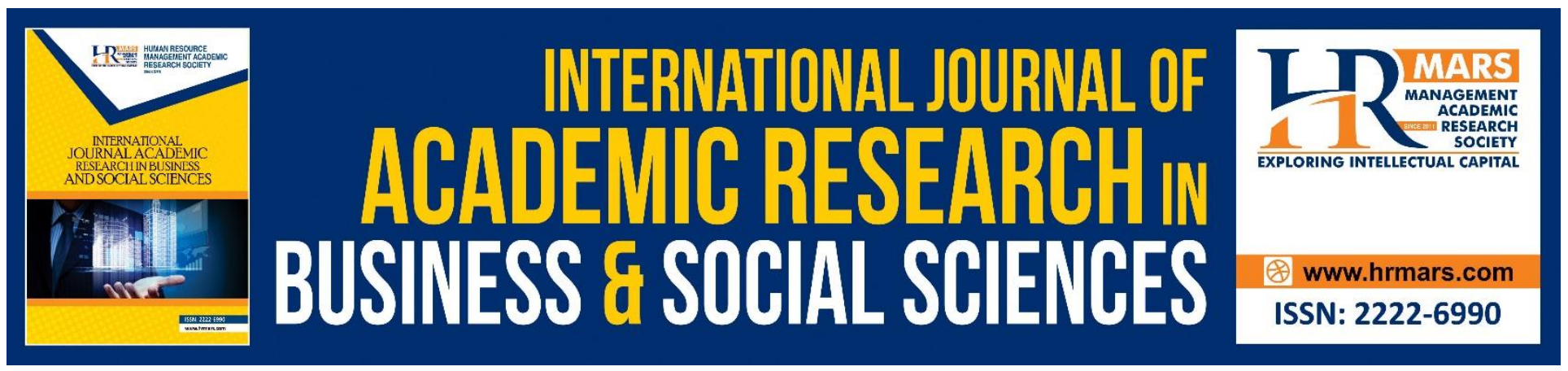

\title{
Auditor Tenure, Audit Firm Rotation and Audit Quality: A Literature Review
}

Hamza K. Qawqzeh, Wan Anisah Endut, Norfadzilah Rashid, Razana Juhaida Johari, Nadiah Abdul Hamid, Zarinah Abdul Rasit

To Link this Article: http://dx.doi.org/10.6007/IJARBSS/v8-i12/5229

DOI: $10.6007 /$ IJARBSS/v8-i12/5229

Received: 11 Nov 2018, Revised: 19 Dec 2018, Accepted: 29 Dec 2018

Published Online: 30 Dec 2018

In-Text Citation: (Qawqzeh et al., 2018)

To Cite this Article: Qawqzeh, H. K., Endut, W. A., Rashid, N., Johari, R. J., Hamid, N. A., \& Rasit, Z. A. (2018). Auditor Tenure, Audit Firm Rotation and Audit Quality: A Literature Review. International Journal of Academic Research in Business and Social Sciences, 8(12), 1314-1324.

Copyright: (C) 2018 The Author(s)

Published by Human Resource Management Academic Research Society (www.hrmars.com)

This article is published under the Creative Commons Attribution (CC BY 4.0) license. Anyone may reproduce, distribute, translate and create derivative works of this article (for both commercial and non-commercial purposes), subject to full attribution to the original publication and authors. The full terms of this license may be seen

at: http://creativecommons.org/licences/by/4.0/legalcode

Vol. 8, No. 12, 2018, Pg. 1314 - 1324

http://hrmars.com/index.php/pages/detail/IJARBSS

JOURNAL HOMEPAGE

Full Terms \& Conditions of access and use can be found at http://hrmars.com/index.php/pages/detail/publication-ethics 


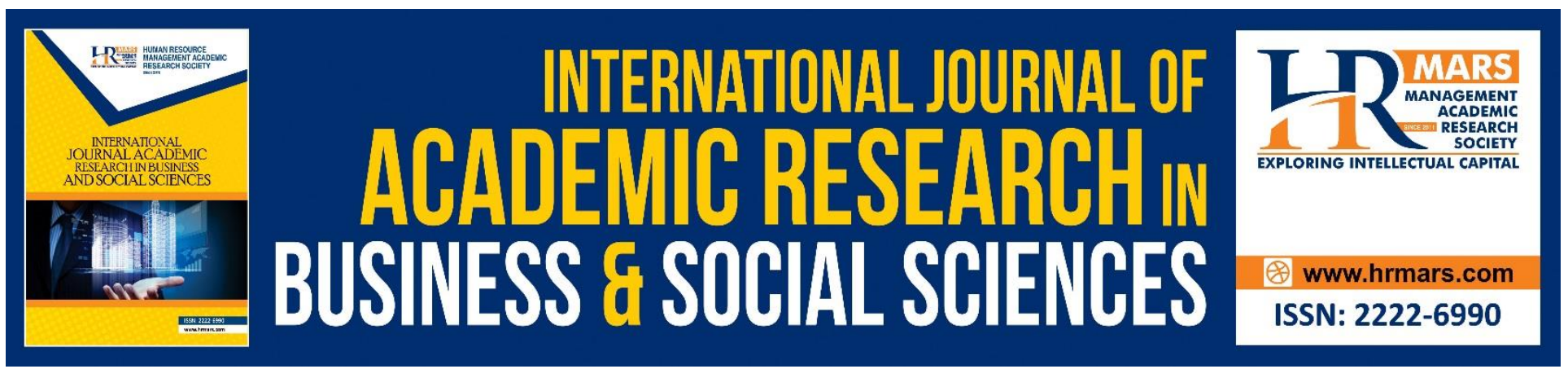

\title{
Auditor Tenure, Audit Firm Rotation and Audit Quality: A Literature Review
}

\author{
${ }^{1}$ Hamza K. Qawqzeh, ${ }^{2}$ Wan Anisah Endut, ${ }^{3}$ Norfadzilah Rashid, \\ ${ }^{4}$ Razana Juhaida Johari, ${ }^{5}$ Nadiah Abdul Hamid, ${ }^{6}$ Zarinah Abdul Rasit \\ 1,2,3Faculty Economics \& Management Science Science, Universiti Sultan Zainal Abidin, Terengganu, \\ Malaysia \\ 4,5,6Faculty of Accountancy, Universiti Teknologi MARA, 42000 Shah Alam \\ Corresponding Author: nikmfadzilah@unisza.edu.my
}

\begin{abstract}
Global audit market is facing several trends and reforms. The aim of these reform is to development the competition in the market of an audit and improve quality of the audit by mandatory auditor rotation and making the financial reports more informative. We make our review around two factors that have big effect on to audit quality, namely auditor tenure and audit firm rotation. Audit quality has long drawn the attention of researchers, investors, auditors, and regulators. To help interested parties better understand the audit quality. We review some studies published about audit tenure, audit firm rotation and audit quality. The purpose of the paper is to review some factors that affect audit quality, namely, auditor rotation and auditor tenure. Whereas the proponents of rotation argue that the long time between the auditor and his client compromises the independence and objectivity, which will affect audit quality as a negatively manner. But the opponents of mandatory rotation argue that switching audit firm will lead to special knowledge in client's work which reduces audit quality and its will lead to additional costs for switching audit firms.

Based on the literature review, we found that there are a few evidence that audit quality is decreased in the presence of audit firm rotation. With regard to auditor tenure, there are two opposing views on the effects of auditor tenure on audit quality. The long relationship between the auditor and his client reduces the auditor's independence, and affecting audit quality in a negatively manner. On the other hand of the debate, switching of the auditors will lead to loss the specific knowledge in the client work which reduces audit quality and incurs additional costs for switching auditors. We conclude that long auditor tenure impair audit quality and independence.
\end{abstract}

Keywords: Auditor Tenure, Audit Firm Rotation, Audit Quality. 
INTERNATIONAL JOURNAL OF ACADEMIC RESEARCH IN BUSINESS AND SOCIAL SCIENCES

Vol. 8, No. 12, Dec, 2018, E-ISSN: 2222-6990 @ 2018 HRMARS

\section{Introduction}

The global financial crisis and the collapse of many large companies have generated increased attention and focus with regard to accounting and external auditing issues. Also; the external audit quality and corporate governance have become fundamental issues after these collapses. The critics put blame on the corporate governance function, board members, the external auditors and audit committees due to the failure to discover the factors that led to this crisis and failures. Audit quality has become an important policy issue following corporate scandals. In the recent past, most failures of companies in the world have raised many fundamental issues on the audit quality and the auditors' independence (Ilaboya \& Ohiokha, 2014; Kharuddin, 2015).

The general assumption is the external auditor is entrusted to assure that the reports and statements are free of errors or misstatements, i.e. "Truth and Justice"; but many of the critics believe that this description understates the value of audit quality. There are many factors that may have an impact on audit quality. Some of these factors are direct factors such as the factors that related to the client's firm. The other type is indirect factors include factors related to the audit firm such as tenure and rotation (Memis \& Cetenak, 2012; Ratanasongtham \& Ussahawanitchakit, 2015).

Moreover, the investors, users, regulators, and shareholders blame the external auditors and corporate governance mechanisms on doing a weak audit due to the recent cases of collapses, earnings management and fraud. Also, the concern regard to the integrity and objectivity of auditing and financial statements is still increasing; which leads to reduction the confidence in these parties. For this; the organizations and regulatory bodies now are need to try to find and study the various influencing factors in order to restore confidence in audit quality. When the audit quality is compromised, the natural consequence is the loss of trust and confidence of the various stakeholders in the financial reporting system (Akhalumeh et al 2017).

Generally, the functions of external auditing and corporate governance might have direct or indirect effects on the confidence of investors and users, financial statements and earnings management. Also the efficient of the external auditor and corporate governance serve as a key to stability and profitability of the company and economic growth. CG has gained greater importance due to the competitiveness across all environments and fields. (Kharuddin, 2015; Bansal \& Sharma, 2016).

In recent times, the financial manipulations, conflicts of interests in organizations, weak internal control systems, management recklessness and greed, ethical dilemmas and corporate dishonesty, manipulation on the part of the internal and external auditors and several fraudulent activities were some of the reasons that led to organizations failures and created a negative image in front of the general public with regards to audit quality. (Adelopo, 2010; Olagunju, 2011; Moses et al, 2016).

Furthermore, the high incidence of corporate failures and scandals in recent years has attracted many empirical investigations on audit quality. Since scandals hurt the corporate entities as well as the stakeholders' wealth, public confidence and by extension hurt the entire economies, a lot of emphasis is usually placed on audit quality. These scandals were mainly caused by audit failures. The later investigations traced the causes of the collapse and highlighted that undetected fraud and weak corporate governance practices were the factors of audit failure. This is what has drawn attention in recent research efforts to audit quality (Malek \& Saidin, 2013; Hosseinniakani, Inácio \& Mota, 2014; Akhalumeh et al 2017). 
The importance of external audit in increasing investors' confidence and developing financial markets is vital. The quality of an audit depends simultaneously on many factors. Also, there is no single factor having the dominant influence on audit quality. For this; there is an urgent need for a deeper and broader investigation about these issues in a comprehensive manner.

There has been research conducted on audit quality; however, there is a lack of consensus and mixed results. Several regulators have expressed the concern that this is an issue of importance and that there is a need for further research studies in this direction to uncover fresh insights. The need for such studies can be appreciated in order to provide a thorough explanation of audit quality (Beattie et al, 2013; Broberg, 2013; Le Vourch \& Morand, 2011).

Thus, there is mixed evidence on the relationships between many variables and audit quality. For this reason, this study extends and contributes to the existing empirical literature in order to contribute in resolving the inconsistency. Such studies are important to undertake at this point in time since there is a significant decrease in the audit quality in recent times (Amer, 2016; Arthur et al, 2017).

\section{Literature}

\section{Audit quality}

Stakeholders, investors, regulators, auditors and society, in general, may have different views about audit quality. This will affect the type of indicators that may be used to assess audit quality. The auditor may define it as completing all requirements of the audit process. The user of reports may define it as discover of the material misstatements. Regulators evaluate the external audit quality as to be identical with the professional standards. Hence, different definitions led to different measurements (Knechel et al, 2012).

There are many definitions of audit quality. Despite continuous studies, there is no any consensus about which definition or measure is the most popular, and the various disclosures and frameworks that exist are incomplete (Knechel et al, 2012; DeFond \& Zhang, 2013).

DeAngelo (1981) defined audit quality as "The probability that the auditor will discover a breach and he will report this breach." Auditing is a socially constructed activity, thus, the meaning of audit quality is socially constructed and is influenced by economic and regulatory factors, interactions between various parties, organizational and societal contexts (Sulaiman, 2011).

Audit quality considered as the heart of the audit process, and the demand for auditing research arises from attempts to understand the role and nature of auditing, particularly with respect to audit quality. Audit quality is very important for all parties; due to the weakness of audit quality is the leading reason for audit failures. After the cases of audit failures and financial scandals, standard setters and regulators have attempted to promote audit quality, for example, the (IAASB). An external audit can contribute in the financial growth of the organizations through achieve financial stability in the financial statements (Kitiwong, 2014).

The importance of audit quality arises from its effect on the reliability and credibility of financial statements and the auditor's opinion; due to the auditor's opinion could be misleading if the external auditor perform a weak work, and this will affect the decisions of stakeholders and users. In this discourse, we believe that the audit quality is very important to protect the financial interests of the stakeholders, investors and the other parties by enhancing the reliability and credibility of financial statements (Sulaiman, 2011; Memis \&Cetenak, 2012). 
Audit quality has been the focus of empirical and theoretical auditing research for the last years. Even though a plenty of studies investigate the audit quality especially in the western countries, there is a lack of empirical evidence from the developing countries context (Kitata, 2016). Very few studies had been conducted in developing countries. Furthermore, prior studies have documented mixed results on the linkage between audit quality and its proxy. Thus, the research question is open for new and thorough evidence to uncovering new insights.

The researchers need to obtain better and new information to understanding audit quality from the regulators, auditors, clients, firms or other sources. With such information, we can continue the scholarly quest for a better understanding of audit quality (Knechel et al, 2012).

There are many external and internal factors that may affect the level of external audit quality. This section will introduce the most popular factors according to the prior literature. Some of these factors such as input factors (audit team behavior, expertise, and audit procedures), output factors (influence of investors and stakeholders and legislative factors) and the interaction between different key actors. All of these factors can be an example on this influence (Nehme, 2013).

\section{Auditor Tenure}

When the relationship between the auditor and the client be for a long time, and then such relationships will affect the independence and the quality of an audit. Previous literature provides mixed evidence on this issue. Several studies report a negative or insignificant relationship on audit quality, while other studies document a positive association.

Generally, debates on audit rotation and tenure arise from the assumption that the length of the relationship between the external auditor and the client may lead to decrease audit quality. Furthermore, tenure of auditor has been associated with several of fraudulent cases, and the previous literature on audit quality has yielded mixed results. If empirical investigations are not carried out, and if the critical policies and solutions are not implemented in order to resolve shortcomings, the concern with regard to independence of the external auditor and audit quality may be worsened with the expected consequences. (Adeyemi \& Okpala, 2011; Ilaboya \& Ohiokha, 2014; Sayyar et al, 2014).

Audit tenure is "the number of periods-years an audit firm, an auditor audits a client or the number of years a company employs the same auditor". Audit tenure has been dissected into large and short audit periods. Long audit tenure might decrease the independence and professional care. On the other hand, shorter audit tenure reflects that the auditors have less knowledge about the client which may lead to low audit quality. Long audit tenure may increase the knowledge about the client's internal operations; but, the downside is that the auditor's independence may get compromised (Islam, 2016; Feleke, 2017). The clients change their auditors for many reasons, one of which is to obtain a reduced audit fee from a new auditor as the new auditor may offer services at a discount to win a new client (Franken, 2011; Oladipupo \& Emina, 2016).

The auditor tenure may affect the quality of audits in a positive or negative manner. There are two arguments that revolve around this issue: (Short tenure) which reflects that the auditor will less his experience in client's work, (Long period) meaning that the independence of auditor may decline (LIM et al, 2010; Knechel et al, 2012). On the other hand, erosion in auditors' objectivity and independence due to the long relationships with the clients is perceived as the reason for a lower 
INTERNATIONAL JOURNAL OF ACADEMIC RESEARCH IN BUSINESS AND SOCIAL SCIENCES Vol. 8, No. 12, Dec, 2018, E-ISSN: 2222-6990 @ 2018 HRMARS

audit quality (Kammenga, 2016). Previous studies on the auditor tenure relying on survey or archival studies have produced mixed evidence regarding the short and long relationships between the external auditor and the client.

Previous studies provided mixed evidence about the relationship between auditor tenure and audit quality. Some studies find that the audit quality is not affected by long tenure. (Agoes, 2014; Bafqi, Addin \& Alavi, 2013; Enofe, Okunega \& Ediae, 2013; Adeyemiet al ,2012). Others find that the audit quality improves with long tenure. (e.g DeFond \& Zhang, 2013; Srinidhi et al, 2010). And Others still believe that audit quality diminishes with long tenure . (e.g Ilaboya \& Ohiokha, 2014; Gelaneh, 2011; Tepalagul \& Lin 2015; LIM et al, 2010; Adeyemi \& Fagbemi,2010; Gelaneh, 2011).

Table 1: Summary of some studies on the effect of auditor tenure on audit quality

\begin{tabular}{|c|c|c|}
\hline Study & Result & Used proxy for audit quality \\
\hline Odia, 2015 & Positive relationship & $\begin{array}{l}\text { A critical review of some of } \\
\text { the empirical and theoretical } \\
\text { researches. }\end{array}$ \\
\hline Adeniyi \& Mieseigha, 2013 & Negative relationship & $\begin{array}{l}\text { The likelihood that a company } \\
\text { employs the services of the } \\
\text { big audit firms. }\end{array}$ \\
\hline Srinidhi et al, 2010 & $\begin{array}{l}\text { The improvement in audit } \\
\text { quality with tenure is not } \\
\text { uniform across client firms. }\end{array}$ & Accruals quality \\
\hline Bell et al, 2012 & Positive relationship & $\begin{array}{l}\text { Internal assessments of audit } \\
\text { quality. }\end{array}$ \\
\hline Diaz et al, 2014 & $\begin{array}{l}\text { Negative relationship until the } \\
\text { sixth year. }\end{array}$ & $\begin{array}{l}\text { If the report is qualified (1) or } \\
\text { unqualified (0). }\end{array}$ \\
\hline Hamid et al, 2014 & Negative relationship & Discretionary accruals \\
\hline Turel et al, 2017 & Positive relationship & Discretionary accruals \\
\hline Bafqi et al, 2013 & No significant relationship & Discretionary accruals \\
\hline Anis, 2014 & Negative relationship & Discretionary accruals \\
\hline James \& Izien, 2014 & Negative relationship & Big 4 audit firm or non-big 4 \\
\hline Ball, 2015 & Positive relationship & IFRS adoption errors \\
\hline Leilina (2015) & $\begin{array}{l}\text { Audit firm tenure has little or } \\
\text { no significance on audit quality. }\end{array}$ & Discretionary accruals \\
\hline Kingstone et al, 2017 & Negative relationship & Questionnaire \\
\hline
\end{tabular}

Therefore, it is concluded that the evidence is mixed and the recent regulatory changes on auditor rotation provides opportunities for future studies on auditor tenure, auditor rotation and audit quality.

\section{Audit firm rotation (Auditor rotation)}

In most situations, investors, general public and shareholders need to have credibility in financial reports, the external auditor who is checking these reports. Also; to reach a good credibility, the 
external auditor should be objective and independent on any party. Many factors can affect the independence and audit quality, auditor's rotation is one of these factors. To prevent the familiarity or the long relationships; the regulatory bodies have proposed the rotation among the external auditors (Al-Khoury et al, 2015). Auditor rotation takes two forms: one is a mandatory rotation, and the other is a voluntary rotation.

In essence, by investigating the audit rotation, the regulators and legislators are trying to enhance audit quality by solving a perceived problem regarding independence threats with a measure which has not been proven to actually solve the problem and truly enhance audit quality (Mendonca \& Persson, 2014; Postma, 2016). Since no evidence has been provided that the measures introduced to solve the problem will actually achieve their objectives, many practitioners are apprehensive about the factors, such as the audit rotation, tenure and industry specialization as having the potential to solve the problem.

Mandatory rotation is the length of time an auditor stays with the client. It requires the auditor to be rotated after a number of years despite the objectivity, independence, efficiency and quality of the auditor, the willingness of the shareholders and the management to keep the auditor (Onwuchekwa et al, 2012). It is "imposition of a limit on the years in which an audit firm with the company" (Sarbanes-Oxley, 2002). It has been proposed as an alternative to auditor tenure, due to the auditor tenure might lead to deterioration in quality of an audit. Therefore, determinants and threats concerning audit quality are a focus of attention in the auditing and accounting literature (Al-Nimer, 2015).

The main objective of mandatory rotation is to prevent the familiarity or the long relationships between the external auditor and clients. The general argument is that through auditor rotation, the long relations and familiarity among the external auditor and client will decrease, it is enables auditors to take a new assessment for client risks, and it is will support the much needed auditor's skepticism and provide a new and fresh perspective which might increase auditor independence and enhance audit quality (Al-Nimer, 2015; Ball, Tyler \& Wells, 2015).

The Sarbanes-Oxley Act OF 2002 that come in to effect in US after the Enron, WorldCom scandals limits the requires that both the lead audit partner and the audit review partner for publicly held companies be rotated at least every five years.

In summarizing the previous studies on auditor rotation, it can have a positive and negative impact on audit quality. The conflicting evidence of the previous studies may cause by many different sides such as how to measure audit quality and the research method used. 
INTERNATIONAL JOURNAL OF ACADEMIC RESEARCH IN BUSINESS AND SOCIAL SCIENCES Vol. 8, No. 12, Dec, 2018, E-ISSN: 2222-6990 @ 2018 HRMARS

Table 2: Summary of some studies on the effect of auditor rotation on audit quality

\begin{tabular}{|c|c|c|}
\hline Study & Result & Used proxy for audit quality \\
\hline Maria, 2016 & $\begin{array}{l}\text { Audit firm rotation enhances } \\
\text { auditor independence and audit } \\
\text { quality. }\end{array}$ & The quality of accruals \\
\hline Kammenga, 2016 & $\begin{array}{l}\text { There is no evidence of an } \\
\text { association between audit firm } \\
\text { rotation (switching) and audit } \\
\text { quality. }\end{array}$ & $\begin{array}{l}\text { The amount of discretionary } \\
\text { accruals and the amount of } \\
\text { abnormal working capital } \\
\text { accruals. }\end{array}$ \\
\hline Chika et al, 2012 & Negative relationship & Questionnaire \\
\hline Ebimobowei \&Keretu, 2011 & Positive relationship & Questionnaire \\
\hline Sotirios, 2014 & Negative association & $\begin{array}{l}\text { The detection and reporting of } \\
\text { control deficiencies by } \\
\text { auditors. }\end{array}$ \\
\hline Kim et al, 2015 & Positive relationship & Discretionary accruals \\
\hline Postma, 2016 & There is no significant evidence. & $\begin{array}{l}\text { amount of abnormal working } \\
\text { capital accruals }\end{array}$ \\
\hline Kingstone et al, 2017 & Positive relationship & Questionnaire \\
\hline
\end{tabular}

\section{Conclusion and Discussion}

The importance of audit quality arises from its effect on the reliability and credibility of financial reports and the auditor's opinion; due to the auditor's opinion could be misleading if the external auditor perform a weak work, and this will affect the decisions of stakeholders and users. In this discourse, we believe that the audit quality is very important to protect the interests of the stakeholders, investors and the other parties by enhancing the reliability and credibility of financial statements.

Audit quality has attracted the attention of researchers, investors, external auditors, and regulators. To help these parties to understand the audit quality, we reviewed some studies published about audit tenure, audit firm rotation and audit quality.

Based on the literature review, we found that there are a little evidence that audit quality is decreasing in the presence of audit firm rotation. SOX has introduced reforms in financial reporting and audit quality. The users of financial statement generally perceive auditor tenure as a threat to audit quality (Auditor's affiliation with client, Long auditor-client relationships and close relationships as a threat to auditor independence.) whereas a little of studies regarding audit tenure and audit quality suggests otherwise; in particular, experience and knowledge-related to the auditor actually improve audit quality.

In literature review there are two views about the influence of tenure on the quality of an audit. The proponents of mandatory rotation argue that the long relation between the auditor and his client compromises the auditor's independence, and it will affect audit quality in a negatively manner. On the other hand, the opponents of auditor rotation argue that the change of the auditors will lead to loss client-specific knowledge which reduces audit quality and incurs additional costs for switching auditors. 
Most studies conclude that long auditor tenure impair audit quality and independence. Some find that long tenure actually improves audit quality. With regard to audit firm rotation, most studies conclude that audit firm rotation actually improves audit quality and auditor independence.

Only a few studies have examined the audit tenure, audit firm rotation and audit quality in developing countries and the evidence is mixed, therefore more research in this arena is needed. Below, we provide some suggestions for future research.

\section{Future Studies}

Further research at the partner/firms level will provide additional evidences into this issue. In addition, abnormally low fees, abnormally high audit fees and the threat of client importance to the independence of the auditor are worth investigating, which may influence ultimately affect audit quality. We call for further research on the topic of audit firm's tenure and rotation using audit fees as a proxy to audit quality, which can provide some insight into this phenomenon.

As the archival tenure and rotation studies mostly use data of the developed countries, it will be useful to conduct such as this research in developing countries such as Middle East countries. We encourage to conduct such as these studies in this relatively under-explored area. Also, research concerning audit quality and auditor independence will benefit from cross-country comparisons due to cultural and regulatory differences. Also; the perceptions, differences in the incentives and behaviors of the multiple parties (auditors, users and clients).

Moreover, corporate governance mechanisms obtained more prominence due to the failures in big companies globally. And many countries now are trying to developing the most acceptable solutions to address corporate governance characteristics, audit committees, ownership structure and board of directors. We call for further research to link between corporate governance characteristics and both of audit tenure and audit firm rotation by their net effect on audit quality.

\section{References}

Adelopo, I. (2010). The impact of corporate governance on auditor independence: A study of audit committess in UK listed companies.

Adeyemi, S. B., \& Fagbemi, T. O. (2010). Audit quality, corporate governance and firm characteristics in Nigeria. International Journal of Business and Management, 5(5), 169-179.

Adeyemi, S. B., \& Okpala, O. (2011). The impact of audit independence on financial reporting: Evidence from Nigeria.

Akhalumeh, P., Agweda, F., \& Ogunkuade, Z. (2017). Corporate characteristics and audit quality: evidence from quoted firms in Nigeria. Journal of Scientific Research and Studies, 4 (3), 59, 66.

Al-Khoury, A. F., Ali, A. E., Al-Sharif, M., Hanania, J., Al-Malki, I., \& Jallad, M. (2015). Auditor independence and mandatory auditor rotation in Jordan. International Business Research, 8(4), 73.

Al-Nimer, M. (2015). Factors affecting mandatory audit rotation: evidence from Jordan. International Journal of Economics and Finance, 7(6), 51.

Amer, M. (2016). Measuring the effect of the board of directors and audit committee characteristics on firm financial performance in Egypt (Doctoral dissertation, Cardiff Metropolitan University). 
INTERNATIONAL JOURNAL OF ACADEMIC RESEARCH IN BUSINESS AND SOCIAL SCIENCES

Vol. 8, No. 12, Dec, 2018, E-ISSN: 2222-6990 @ 2018 HRMARS

Arthur, N., Endrawes, M., \& Ho, S. (2017). Impact of partner change on audit quality: An analysis of partner and firm specialisation effects. Australian Accounting Review, 27(4), 368-381.

Bafqi, H. D., Addin, M. M., \& Alavi, A. (2013). The Relationship between Auditor's Characteristics and Audit Quality. Interdisciplinary Journal of Contemporary Research in Business, 5(3).

Ball, F., Tyler, J., \& Wells, P. (2015). Is audit quality impacted by auditor relationships?. Journal of Contemporary Accounting \& Economics, 11(2), 166-181.

Bansal, N., \& Sharma, A. K. (2016). Audit committee, corporate governance and firm performance: Empirical evidence from India. International Journal of Economics and Finance, 8(3), 103.

Beattie, V., Fearnley, S., \& Hines, T. (2013). Perceptions of factors affecting audit quality in the postSOX UK regulatory environment. Accounting and Business Research, 43(1), 56-81.

Broberg, P. (2013). The auditor at work: A study of auditor practice in Big 4 audit firms (Doctoral dissertation, Department of Business Administration, School of Economics and Management, Lund University).

DeFond, M., \& Zhang, J. (2014). A review of archival auditing research. Journal of Accounting and Economics, 58(2-3), 275-326.

Enofe, A. O., Ediae, O. O., \& Ejiemen, C. O. (2013). Audit Quality and Auditors Independence in Nigeria: An Empirical Evaluation. Journal of Finance and Accounting, 4(11.2013).

Feleke, B. T. (2017). Auditors Perception of Audit Quality in Ethiopia (Doctoral dissertation, Addis Ababa University).

Franken, N. E. (2011). The influence of investor protection on the relationship between positive abnormal audit fees and earning quality (Doctoral dissertation, Master Thesis, the University of Tilburg. Netherland). Retrieved from http://unsw. edu. au).

Gelaneh, A. (2011). The Impact of Extended Audit Tenure on Auditors Independence and Audit Quality: An Empirical Study on Ethiopian private audit firms. Addis Ababa University.

Gelaneh, A. (2011). The Impact of Extended Audit Tenure on Auditors Independence and Audit Quality: An Empirical Study on Ethiopian private audit firms. Addis Ababa University.

Hagman Mendonca, S., \& Persson, L. (2014). Audit Quality from a Client Company Perspective-Drivers of audit quality and the effects of a voluntary audit firm rotation.

Hosseinniakani, S., Inácio, C. H., \& Mota, R. (2014). A review on audit quality factors. International Journal of Academic Research in Accounting, Finance and Management Sciences, Vol. 4 (2), pp. 243-254.

Ilaboya, O. J., \& Ohiokha, F. I. (2014). Audit firm characteristics and audit quality in Nigeria. International Journal of Business and Economics Research, 3(5), 187-195.

Islam, M. S. (2016). Impact of non-audit services and tenure regulations on auditor independence and financial reporting quality: Evidence from the UK (Doctoral dissertation, Cardiff University).

Kammenga, M. (2016). Audit firm-client relationship: influence of audit firm tenure and audit firm switching on the audit quality of client firms in Italy.

KHARUDDIN, K. A. B. M. (2015). The effects of audit firm and partner industry specialisation and corporate governance on audit quality and earnings quality.

Kitata, S. (2016). Factors affecting quality of External Auditing: The case of Ethiopian Commercial Banks. 
INTERNATIONAL JOURNAL OF ACADEMIC RESEARCH IN BUSINESS AND SOCIAL SCIENCES

Vol. 8, No. 12, Dec, 2018, E-ISSN: 2222-6990 C 2018 HRMARS

Kitiwong, W. (2014). Earnings Management and Audit Quality: Evidence from Southeast Asia (Doctoral dissertation, University of York).

Knechel, W. R., Krishnan, G. V., Pevzner, M., Shefchik, L. B., \& Velury, U. K. (2012). Audit quality: Insights from the academic literature. Auditing: A Journal of Practice \& Theory, 32(sp1), 385421.

Le Vourc'h, J., \& Morand, P. (2011). Study on the effects of the implementation of the acquis on statutory audits of annual and consolidated accounts including the consequences on the audit market. Final report.

LIM, C. Y., \& TAN, H. T. (2010). Does auditor tenure improve audit quality? Moderating effects of industry specialization and fee dependence. Contemporary Accounting Research, 27(3), 923957.

Malek, M., \& Saidin, S. F. (2013). Audit services fee, non-audit services and the reliability of earnings. International Journal of Trade, Economics and Finance, 4(5), 259.

Memis, M. U., \& Cetenak, E. H. (2012). Earnings management, audit quality and legal environment: An international comparison. International Journal of Economics and Financial Issues, 2(4), 460469.

Moses, T. E. M. P. L. E., Ofurm, C., \& Egbe, D. S. (2016). Audit committee characteristics and quality of financial reporting in quoted Nigerian banks. International Journal of Advanced Academic Research, 2(5), 1-10.

Nehme, R. (2013). Dynamics of audit quality: behavioural approach and governance framework: UK evidence (Doctoral dissertation, Durham University).

OLADIPUPO, A. O., \& MONYE-EMINA, H. E. (2016). Do abnormal audit fees matter in Nigerian audit market?. International Journal of Business and Financial Management Research, 4, 64-73.

Olagunju, A. (2011). An empirical analysis of the impact of auditors independence on the credibility of financial statement in Nigeria. Research journal of finance and accounting, 2(3), 82-99.

Onwuchekwa, J. C., Erah, D. O., \& Izedonmi, F. (2012). Mandatory audit rotation and audit quality: Survey of Southern Nigeria. Research Journal of Finance and Accounting, 3(8), 70-77.

Postma, E. (2016). The effects of audit firm rotation on audit quality: does audit firm rotation improve audit quality?(Master's thesis, University of Twente).

Ratanasongtham, W., \& Ussahawanitchakit, P. (2015). Strategic audit planning and audit quality: an empirical research of CPAs in Thailand. The Business \& Management Review, 7(1), 384.

Sarwoko, I., \& Agoes, S. (2014). An empirical analysis of auditor's industry specialization, auditor's independence and audit procedures on audit quality: evidence from indonesia. Procedia-Social and Behavioral Sciences, 164, 271-281.

Sayyar, H., Basiruddin, R., Zaleha, S., Rasid, A., \& Sayyar, L. (2014). Mandatory audit firm and audit partner rotation.

Srinidhi, B., Leung, S., \& Gul, F. A. (2010). Auditor tenure and audit quality: The role of the demand for unique client specific knowledge.

Sulaiman, N. A., \& Turley, S. (2011). Audit Quality in Practice: A Study of Perceptions of Auditors, Audit Committee Members and Quality Inspectors (Doctoral dissertation, University of Manchester).

Tepalagul, N., \& Lin, L. (2015). Auditor independence and audit quality: A literature review. Journal of Accounting, Auditing \& Finance, 30(1), 101-121. 